\title{
Technical applications of plasma treatments: current state and perspectives
}

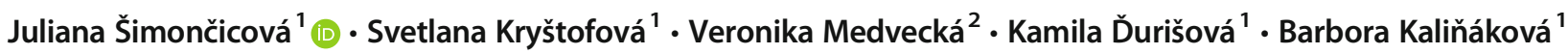

Received: 28 February 2019 / Revised: 25 April 2019 / Accepted: 26 April 2019 / Published online: 15 May 2019

(C) Springer-Verlag GmbH Germany, part of Springer Nature 2019

\begin{abstract}
Rapidly evolving cold atmospheric pressure plasma (CAPP)-based technology has been actively used not only in bioresearch but also in biotechnology, food safety and processing, agriculture, and medicine. High variability in plasma device configurations and electrode layouts has accelerated non-thermal plasma applications in treatment of various biomaterials and surfaces of all sizes. Mode of cold plasma action is likely associated with synergistic effect of biologically active plasma components, such as UV radiation or reactive species. CAPP has been employed in inactivation of viruses, to combat resistant microorganisms (antibiotic resistant bacteria, spores, biofilms, fungi) and tumors, to degrade toxins, to modify surfaces and their properties, to increase microbial production of compounds, and to facilitate wound healing, blood coagulation, and teeth whitening. The minireview provides a brief overview of non-thermal plasma sources and recent achievements in biological sciences. We have also included pros and cons of CAPP technologies as well as future directions in biosciences and their respective industrial fields.
\end{abstract}

Keywords Cold atmospheric pressure plasma $\cdot$ Cold plasma applications $\cdot$ Biological decontamination $\cdot$ Plasma mode of action

\section{Introduction}

The term plasma was first used by Irving Langmuir in 1928 and describes quasi-neutral ionized or partially ionized gas in electric discharge. The plasma consists of variety of particles, neutral atoms and molecules, charged particles (electrons and ions), metastable particles (excited atoms and molecules, radicals), and photons (Bellan 2008). Depending on temperature of particles, plasma can be classified into two categories: equilibrium or thermal plasma and non-equilibrium or nonthermal plasma. The thermal plasma is characterized by an almost completely ionized gas and high temperature of at least $15,000 \mathrm{~K}$ (Roth 2001). The non-thermal or cold plasma is a partially ionized gas with temperature generally close to room

Juliana Šimončicová

juliana.simoncicova@stuba.sk

$\bowtie$ Barbora Kaliňáková

barbora.kalinakova@stuba.sk

$1 \quad$ Institute of Biochemistry and Microbiology, Faculty of Chemical and Food Technology, Slovak University of Technology,

Bratislava, Slovakia

2 Department of Experimental Physics, Faculty of Mathematics, Physics and Informatics, Comenius University, Bratislava, Slovakia temperature (maximum $340 \mathrm{~K}$ ). Since the treatment by cold plasma is delivered at room temperature, damaging effects on biological tissues and thermolabile matrices can be minimized while still maintaining disinfection and sterilization efficacy. To date, several types of cold plasma have been developed. Cold atmospheric pressure plasma (CAPP) is frequently used in many life science and agricultural technologies such as medical treatment or plant and food preservations. This review presents recent developments, challenges, and future options of CAPP in biological decontamination and interactions with various tissues and organisms. In the review, CAPP chemistry, energy source generation, equipment design, and conditions are summarized together with application and modes of action in biological systems.

\section{Cold atmospheric pressure plasma systems}

CAPP as a novel technology expanded very quickly to several industrial and medical fields (Table 1). In biological applications, the most commonly used plasmas are Atmospheric Pressure Plasma Jets (APPJs) and Dielectric Barrier Discharges (DBDs). Low-powered discharges APPJs form a wide group of small plasma torches working at low power and generating cold CAPP. APPJs consist of two concentric 


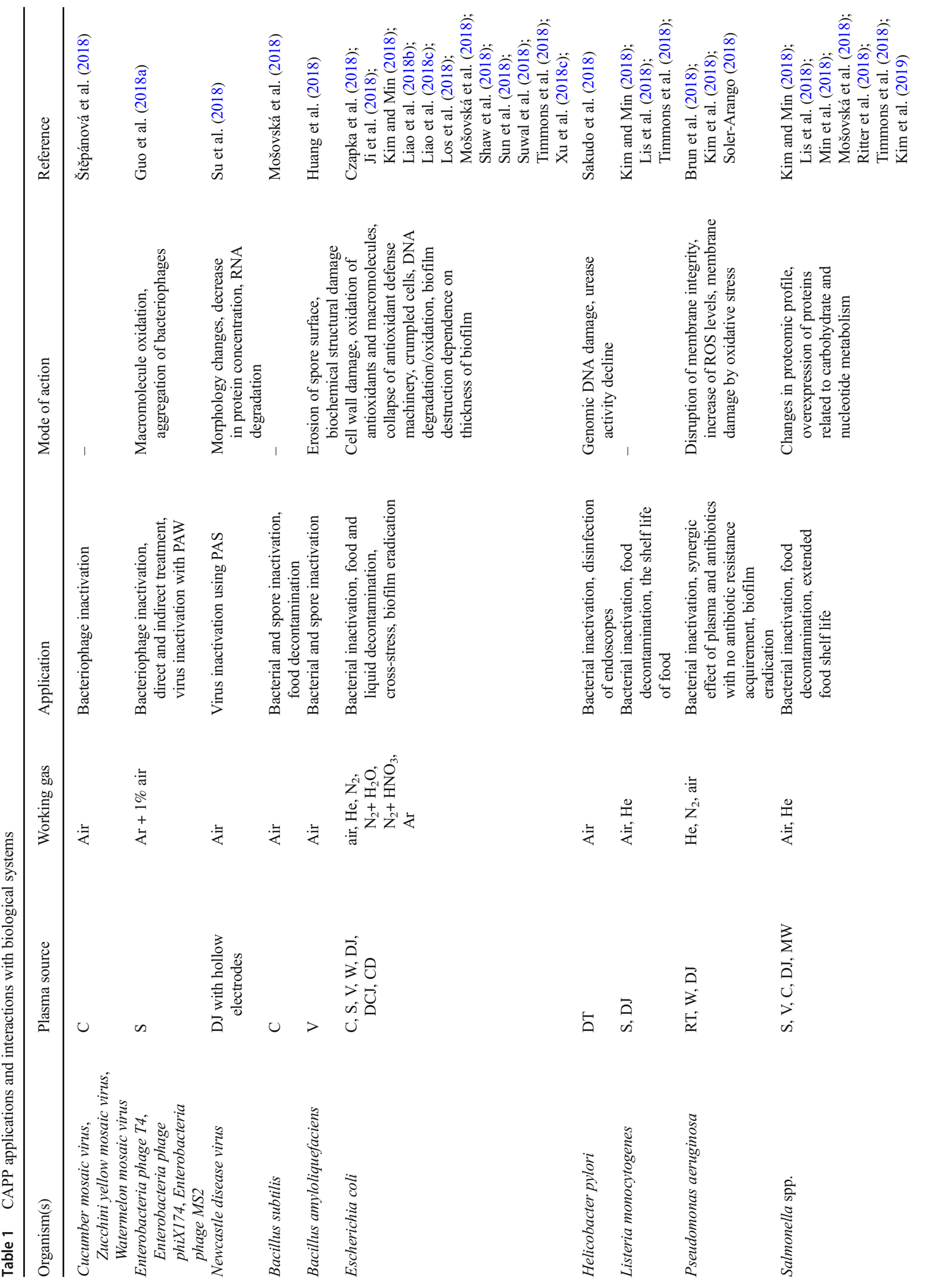




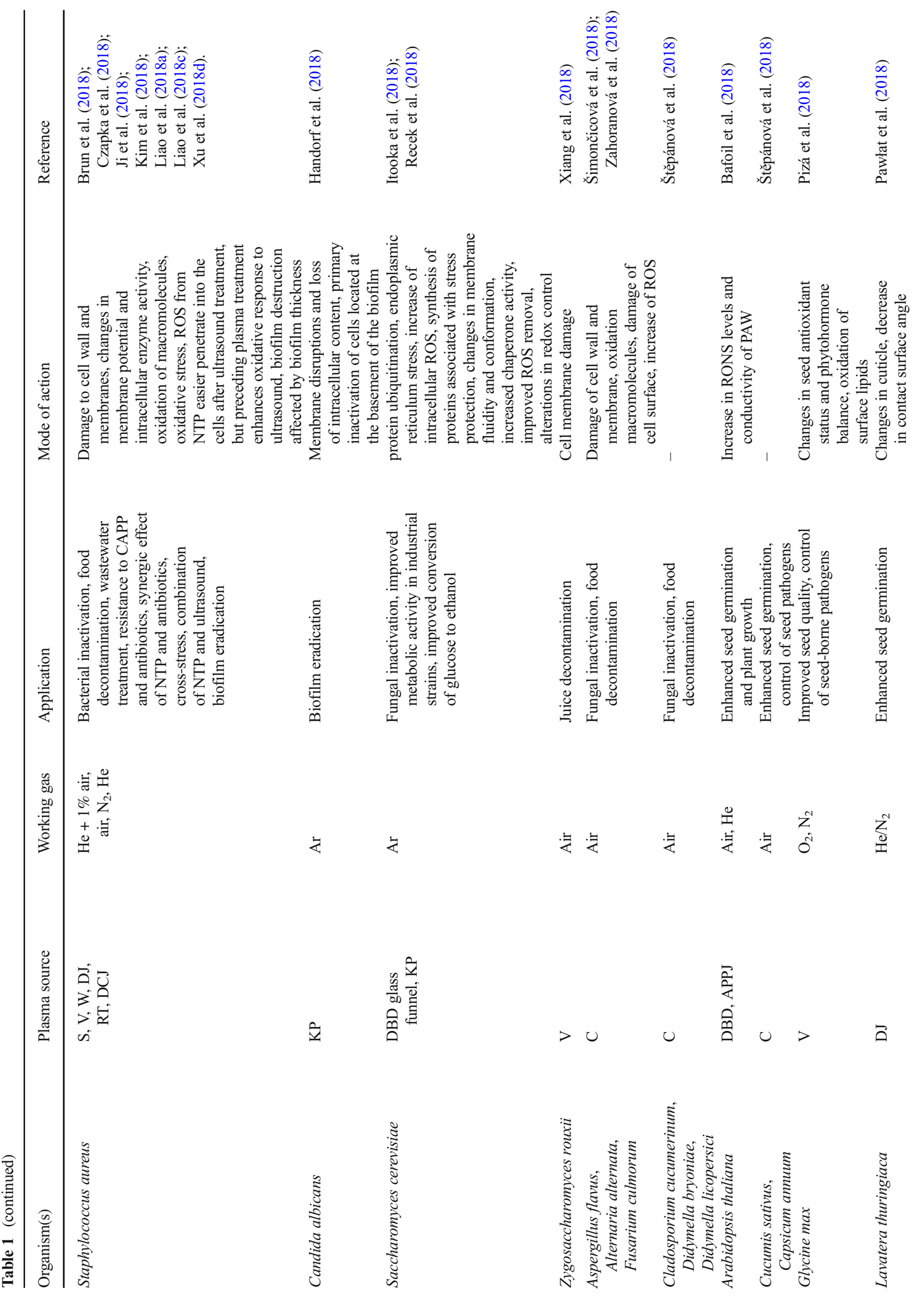



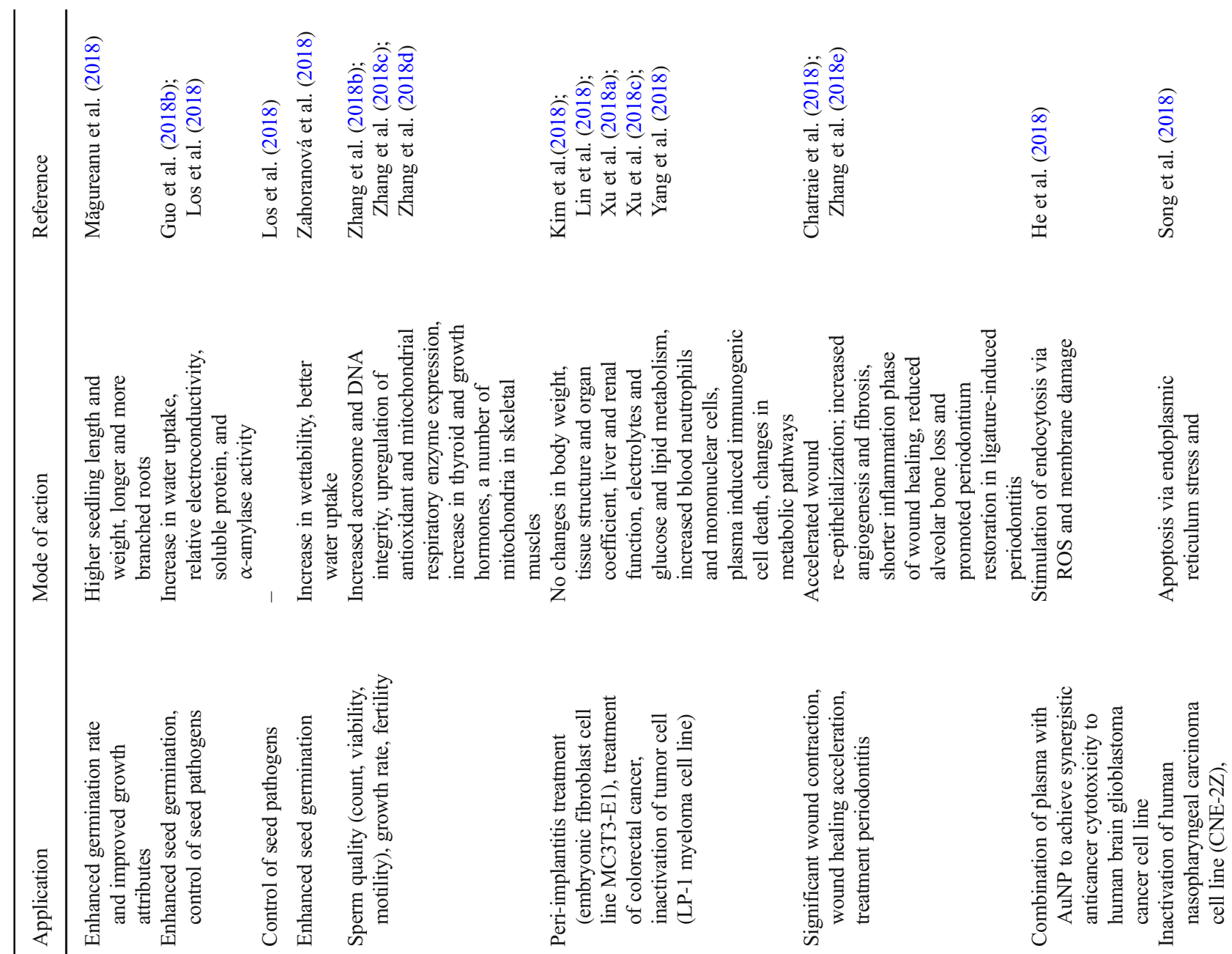

安安安

$\stackrel{0}{1}$
ì
$\stackrel{y}{4}$

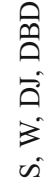

这

定

里

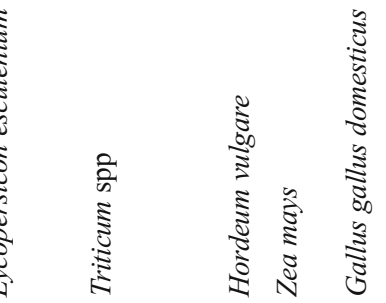

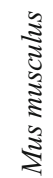

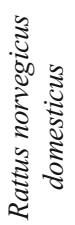

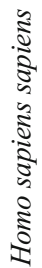




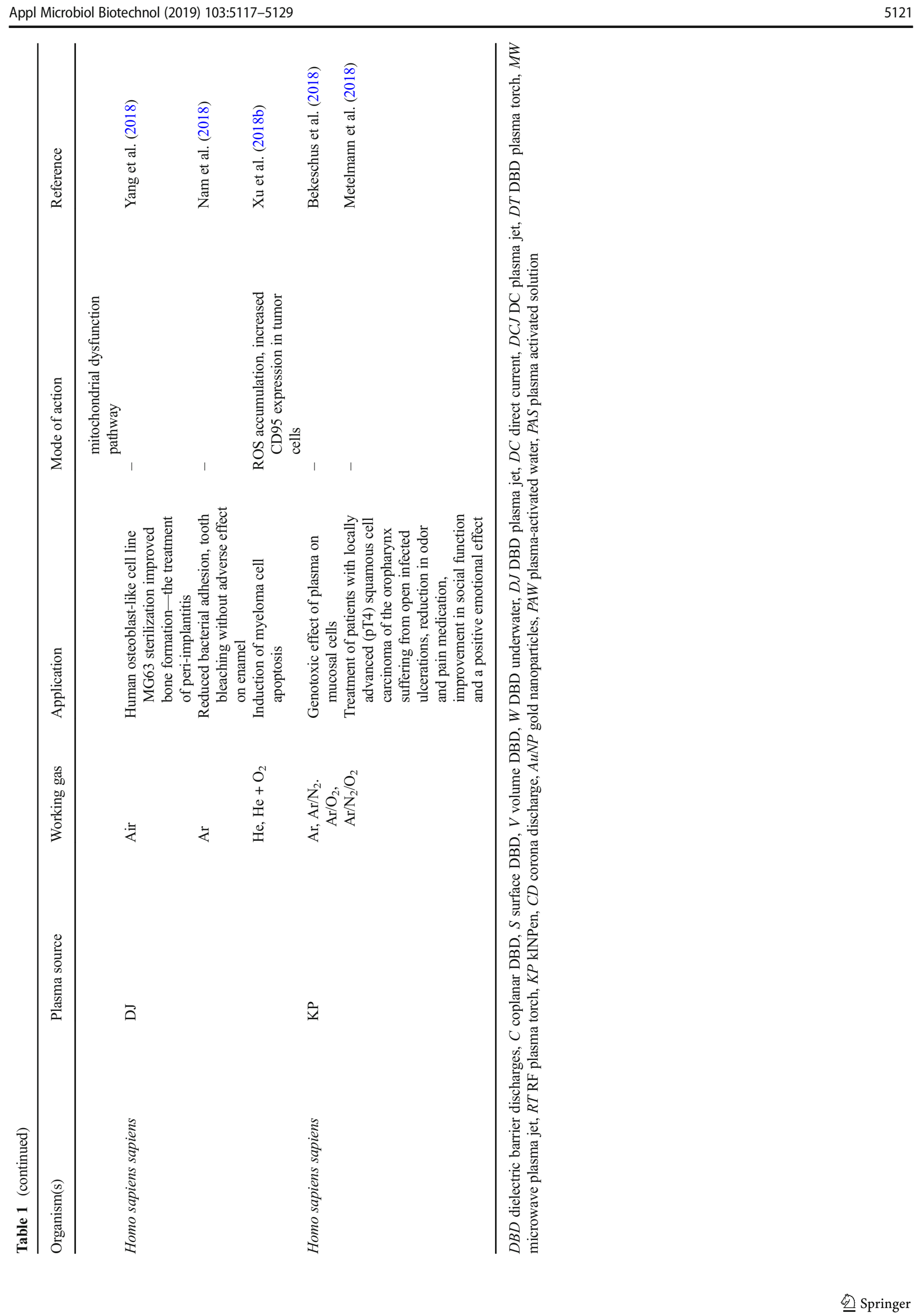


electrodes with a flowing gas. APPJs can be categorized according to configurations and used materials as dielectric-free electrode jets, DBD jets, DBD-like jets, and single electrode jets (Lu et al. 2012). The typical geometry of APPJs is depicted in Fig. 1 a-c. Short distance between electrodes allows for low applied electric voltage, and gas flow (mainly noble gases such $\mathrm{He}$ or Ar) ensures low temperature character of plasma. APPJs can be supplied by direct, pulsed direct, or high frequency alternating currents (radio frequency and microwave). To increase the reactivity of plasma in some settings, small amount of reactive gas is supplemented (e.g., $1 \%$ of $\mathrm{O}_{2}$ ). To minimize contact with the environment, the $\mathrm{N}_{2}$ and air APPJs require special geometry (i.e., electrode position). APPJs can be used in direct treatment of objects, when the treated material is in direct contact with plasma or indirect treatment, when the samples do not come into direct contact with plasma but only with active particles previously generated in plasma (Weltmann and von Woedtke 2011).

DBDs are called in some cases as "silent" or "atmospheric pressure glow" discharges (Kogelschatz et al. 2003). Their defining feature is the presence of dielectric material between the electrodes. DBDs usually operate at frequencies of 50-500 $\mathrm{kHz}$ and voltage amplitude in the order of tens $\mathrm{kV}$. The electrode gap ranges from tens of microns to several $\mathrm{cm}$. Volume and Surface DBDs (VDBDs and SDBDs) are the most common DBDs configurations employed in treatment of biological systems. The VDBD configuration known incorrectly as "industrial corona" has been frequently used in industry (Pykönen et al. 2009). It consists of two parallel plates in planar or cylindrical arrangements (Fig. 1d) and operates in a uniform glow discharge mode. The SDBD contains rows of parallel electrodes (or an electrode grid) separated from the second plate electrode by a dielectric barrier layer (Fig. 1e), and plasma is formed in a non-uniform electric field. In the SDBD configuration, the discharge gap is flexible, allowing the treatment of objects of various sizes. However, the degradation of electrodes occurs, and the lifetime of the device is limited due to the contact of plasma with electrodes (Kogelschatz et al. 2003). The advantages of VDBD and
SDBD are combined in Coplanar DBD (CDBD) (Fig. 1f) where the pairs of parallel linear electrodes with opposite polarity are covered by a dielectric barrier layer. DBDs are used in ozone generation, excimer lamps, $\mathrm{CO}_{2}$ lasers, plasma displays, water purification, and air and surface modifications (Kogelschatz et al. 2003; Chirokov et al. 2005).

\section{Mode of plasma action}

Mode of CAPP action has been studied from single cell to multicellular organisms for over 15 years (Laroussi et al. 2003; Fridman et al. 2006). The recent studies explore wide spectrum effects of CAPP, such as microbial decontamination, cancer treatment, modification of oligomeric components in plant seeds, food preservation and functionality, and microbial and animal breeding (Table 1). The interaction between CAPP and cells is very complex. It is affected by the CAPP design, the dose of energy input, working gas, and treatment time as well as biological target size and structure. The reactive oxygen and nitrogen species (RONS), charged particles, and UV radiation seem to play a key role in interactions with biological systems, although it is hard to pinpoint which component of the CAPP has the most significant impact (Brun et al. 2018; Ji et al. 2018; Šimončicová et al. 2018). It has been presumed that the physical and chemical factors could act independently or in synergy in plasma treatments. Multiple mechanisms participating in plasma-cell interactions have been described: (a) pore formation and cell erosion through etching by atomic and molecular radicals, (b) photo-desorption and subsequent chemical bond breakage, (c) direct DNA destruction triggered by UV irradiation and reactive species, and (d) formation, diffusion, and accumulation of oxygenated species that induce oxidative damage to lipids, proteins (cysteine and amino acids with aromatic rings), polysaccharides, and DNA (Takai et al. 2012; Lackmann et al. 2013; Graves 2014; Arjunan et al. 2015; Edengeiser et al. 2015; Van Der Paal et al. 2016; Brun et al. 2018; Handorf et al. 2018; Huang et al. 2018; Ji et al. 2018; Sakudo et al. 2018; Šimončicová et al. 2018).

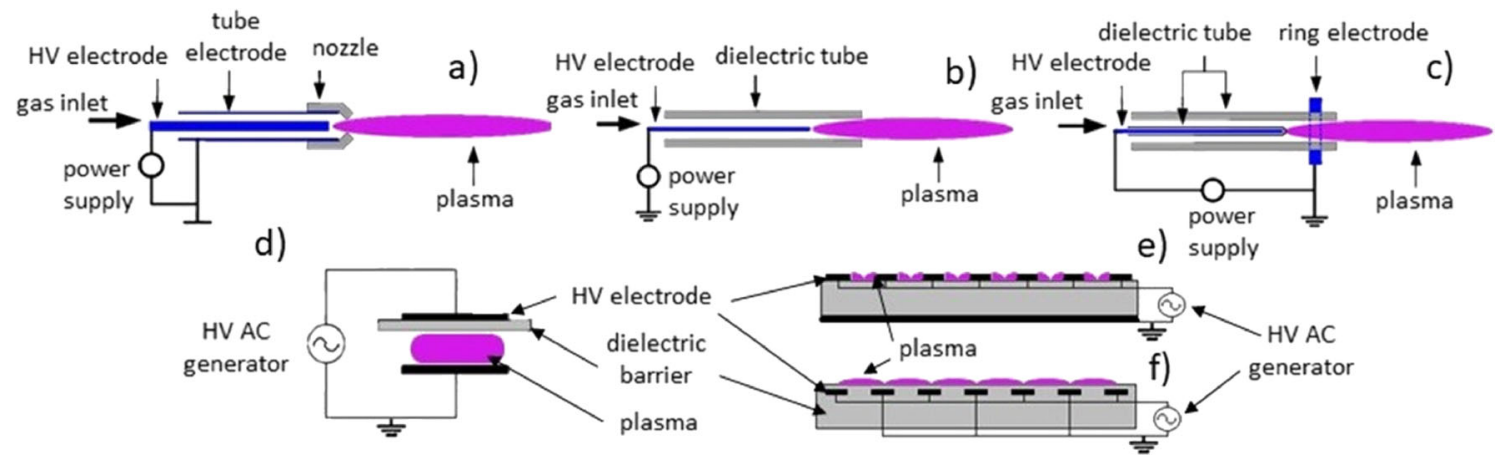

Fig. 1 Typical configurations of APPJ: a, dielectric-free plasma jet; b, single electrode plasma jets; c, DBD-plasma jets, and DBD; d, volume-planar arrangement; e, surface and f, coplanar DBD (Kogelschatz et al. 2003; Lu et al. 2012); high-voltage alternating current (HV AC) 


\section{Bacterial decontamination}

CAPP applications in microbial decontamination has become especially important when traditional disinfection techniques fail or the inactivation of resistant bacterial strains such as methicillin-resistant $S$. aureus (Liao et al. 2018a) or sporeforming Bacillus amyloliquefaciens (Huang et al. 2018) has to be eradicated. The differences related to cell structure, size, cell density, metabolic activity, and ability to deal with reactive molecules in microorganisms still remain not well understood. CAPP exerts different effects on Gram-positive and Gram-negative bacteria that differ in cell envelope structures (Mai-Prochnow et al. 2016; Nishime et al. 2017). Grampositive bacteria differ from Gram-negative by thicker cell wall and therefore, as a group display higher tolerance to cold plasma (Mai-Prochnow et al. 2016). Gram-negative bacteria possess an outer membrane that is highly sensitive to peroxidation and more prone to electrostatic disruption during cold plasma treatment (Mai-Prochnow et al. 2016). For example, rod-shaped, Gram-negative $P$. aeruginosa exhibited visible morphological deformities in cell shape while minor morphological changes were observed in Gram-positive coccal Enterecoccus faecalis (Nishime et al. 2017). Interestingly, E. faecalis exhibited overall higher sensitivity to CAPP treatment in comparison to $P$. aeruginosa, indicating possible involvement of other unspecified factors. Although, cell envelope structure plays a crucial role in microbial defense in cold plasma treatment other contributing factors need to be considered.

Bacteria are different from each other not only by cell wall composition but by shape of individual cells as well. The important elements of bacterial cell shape include the physical properties of the cell wall and the processes responsible for its synthesis and remodelling, and the balance between cell-wall extension force and turgor pressure (Campas and Mahadevan 2009; Furchtgott et al. 2011). As plasma components collide with the surface of the cell, electrostatic disruption transpires, triggering tensions in the cell wall, and mechanical rupturing and leakage of the cell content (Laroussi et al. 2003). It has been suggested that the electrostatic disruption would be intensified in rod- and spiral-shaped cells due to the enhanced field gradients on the curved areas of the cell wall (Stoffels et al. 2008). The inactivation efficacy of CAPP can be therefore influenced by the shape of bacterial cells with more resistant spherical cells (cocci) than rod-shaped cells (bacilli). Different CAPP inactivation efficacy was demonstrated in deactivation of the two Gram-positive bacteria, $L$. monocytogenes and $S$. aureus, where spherical $S$. aureus exhibited higher resistance to CAPP treatment than rodshaped L. monocytogenes (Ziuzina et al. 2015).

The effect of plasma is related to numerous cell-specific factors that have not been studied or even considered in cellcold plasma interaction. Most of studies use high concentration of bacteria grown either in liquid or in monolayers on various matrices. There are not many reports describing the effect of cell concentration and/or growth phase on the CAPP decontamination performance. In the recent study, an impact of bacteria concentration on decontamination with CAPP was reported in all tested bacteria, S. aureus, S. pseudintermedius, Streptococcus canis, Pasteurella multocida, and $P$. aeruginosa with lower concentrations being more susceptible than higher concentrations. This effect was especially profound in $S$. pseudintermedius and Sc. canis (Winter et al. 2018).

In comparison with planktonic cells, bacterial biofilms display increased resistance to most environmental stresses including antibiotic treatment, starvation, and oxidative stress (Bridier et al. 2015). In response to enhanced antibiotic resistance of biofilms, the research has focused on alternative approaches for an efficient inactivation and removal of bacterial biofilms. Introducing CAPP technology in biofilm eradication has proven to be a potent inactivation approach against a range of biofilm forming microorganisms (Czapka et al. 2018; Handorf et al. 2018; Soler-Arango 2018). The efficiency of CAPP inactivation was found to be bacterial species and strain dependant. The CAPP treatment reduced populations of Gram-negative E. coli biofilms more efficiently than those of Gram-positive L. monocytogenes and S. aureus (Ziuzina et al. 2015).

\section{Fungal decontamination}

Significant differences were found in decontamination efficacy of bacterial and fungal cells. The experimental data confirmed that fungi were intrinsically more resistant to CAPP exposure than bacteria (Zahoranová et al. 2018). Although the eukaryotic microorganisms required longer treatment time by CAPP, they were efficiently inactivated after several minute-long exposure (Itooka et al. 2018; Recek et al. 2018; Zahoranová et al. 2018). The inactivating mechanism of filamentous fungi by CAPP resembles the one described in bacteria. Bacterial or fungal death was preceded by damage of cell envelope structures and oxidation of cell macromolecules (Šimončicová et al. 2018).

Most fungal species do not belong to human or animal pathogens but often infect plants and crops. The infection process is associated by mycotoxin production which could pose a serious threat to food safety and public health, and cause a huge economic loss (Wu 2015). Some mycotoxins are relatively thermostable, but their destruction often requires UV radiation or ozone treatment. Both ozone formation and partly also UV radiation often occur during plasma generation together with other reactive components in dependence of working gas and discharge properties. The CAPP has become a hot candidate in non-thermal and non-chemical mycotoxin 
detoxification strategy (Hassan and Zhou 2018). It has been successfully used to degrade deoxynivalenol, zearalenone, enniatins, fumonisin B1, T2 toxin, and sterigmatocystin (ten Bosch et al. 2017). Almost complete degradation of cancerous aflatoxin by CAPP has been achieved in corn (Shi et al. 2017) and nuts (Siciliano et al. 2016).

\section{Plasma agriculture and food safety and functionality}

CAPP has demonstrated efficacy in decontaminating food like meat, poultry, fruits, and vegetables. Non-thermal plasma proved to be a suitable method for decontamination of food surfaces as well as liquid food without compromising the safety and quality attributes (Table 1). Plasma can also be generated in liquids, but special configurations are required for plasma discharge in water such as pulsed corona, arc, and spark (Misra et al. 2016). Plasma can be employed in water (Ji et al. 2018) or juice decontamination (Xiang et al. 2018), and in preparation of plasma-activated water (PAW) that contains active species used to treat biological material (Guo et al. 2018a; Suwal et al. 2018; Xu et al. 2018b). Many studies have shown the effective use of CAPP for decontamination of liquid food such as milk (Coutinho et al. 2018), apple juice (Xiang et al. 2018; Liao et al. 2018b), and orange juice (Groot et al. 2018).

Food safety requires not only microbial inactivation, mycotoxin, and pesticide removal but also long-term preservation. Cold plasma can degrade pesticide residues on fruits or vegetables (Phan et al. 2018). Some of the benefits of CAPP in food industry could be attributed to CAPP-mediated changes in food chemical components and functionality, such as flour rheological properties (Bahrami et al. 2016). The effect of CAPP on food qualities, e.g., $\mathrm{pH}$, proteins/enzymes, carbohydrates, lipids, polyphenols, vitamins, and antioxidant capacity, have been recently reviewed by Coutinho et al. (2018), Cullen et al. (2018), Muhammad et al. (2018), and Pankaj (2018).

Several recent studies have demonstrated that CAPP treatment improved germination rate of many types of seeds (Table 1), and this could eventually enhance food and feed production. Plasma treatment of seeds causes changes in their surface properties, resulting in better seed wettability and water uptake, and consequently increased germination (Zahoranová et al. 2018). Contrary to microbial inactivation by RONS, these reactive species could increase seed germination in plants, and trigger significant changes in amylase, peroxidase, and superoxide dismutase activities (Zhang et al. 2018a). The indirect interaction of reactive species in PAW during irrigation has been demonstrated to enhance growth of radish, tomato, and sweet pepper plants in controlled conditions (Sivachandiran and Khacef 2017).

\section{Plasma medicine}

In plasma medicine, treatment of small areas has led development of special microplasma geometries (Foest et al. 2006). The non-thermal plasma has been employed in microbial and viral inactivation, treatment of various skin diseases, wound healing, blood coagulation, teeth whitening, and antitumor therapy without significant impact on normal cells (Bekeschus et al. 2018; Nam et al. 2018; Saadati et al. 2018; $\mathrm{Xu}$ et al. 2018c). Cancer cells differ from normal cells in metabolism and signalling during oxidative stress. They have higher baseline ROS levels and higher expression of scavenging enzymes. The additional increase of RNOS by plasma exposure is therefore more detrimental to them than to normal cells that are able to defend themselves against exogenous ROS and maintain ROS levels below threshold associated with cell death (Graves 2014).

\section{Animal and microbial breeding}

Plasma is considered a powerful mutagenesis tool. The plasma induces faster and greater DNA damage in vivo than conventional mutagenesis tools (Zhang et al. 2015). To date, several reports have published the isolation of mutants after nonthermal plasma exposure. CAPP was successfully employed in generation of $B$. subtilis mutants with a $35 \%$ increased yield of recombinant alkaline $\alpha$-amylase (Ma et al. 2015), Schizochytrium strain with 1.8 -fold increase of docosahexaenoic acid (Zhao et al. 2018), and Streptomyces bingchenggensis strain with 2-fold increase of 5 oxomilbemycins A3/A4 (Wang et al. 2014). S. cerevisiae mutants isolated after APPJ treatment displayed changes in cell membrane structure, increase in hexokinase 2 activity, and conversion of glucose to ethanol (Recek et al. 2018).

Non-thermal plasma has been recently employed in animal breeding experiments in which reproductive and embryonic cells as well as young animals have been treated by plasma. DBD plasma treatment of chicken sperm has improved viability, motility, acrosome and DNA integrity, and ultimately the total fertility (Zhang et al. 2018b). Chicken eggs were also subjected to plasma treatment. Four-day-incubated fertilized eggs treated with plasma exhibited higher growth rate in chickens after hatching, and significant increase in growth and thyroid hormones (Zhang et al. 2018c). The plasma treatment of fertilized eggs improved male reproductive capacity by improvement of sperm count and motility, but no effect on female reproduction, such as egg-laying rate and egg weight, has been observed (Zhang et al. 2018d). While plasma treatment has promoted chicken embryonic development, the prolonged plasma exposure resulted in dose-dependent embryonic death (Zhang et al. 2017). 


\section{Perspectives and limitation}

Plasma treatment provides many advantages, but also limitations (Fig. 2). Non-thermal plasma that operated at low pressure required relatively high investment costs. These initial expenses, maintenance, and servicing costs had been significantly reduced in CAPP generated in ambient air. CAPP is often described as a versatile, rapid, cost-effective, environmentally friendly, energy and water saving technology. It represents a chemical-free process that is more flexible and efficient in decontamination in comparison to pharmaceuticals. The CAPP treatment of antibiotic resistant bacteria could therefore constitute a promising alternative to tackle multidrug resistance.

Although, non-thermal plasma is currently employed in various medical treatments, industrial CAPP application in decontamination still remains problematic. One of the major problems is plasma dose determination that could be applied in treatment protocols. An effective dose of plasma is defined by plasma source configuration, working gas composition, biological target structure, and dose determination with maximal positive effect without matrix damage. Matrix surface structure itself also influences plasma treatment effectivity. This could be especially pronounced during decontamination treatment of uneven surfaces where plasma treatment may not be as effective. The rough surfaces often hide bacterial cells that could escape plasma exposure. Moreover, bacteria can form aggregates, colonies, or biofilms that protect bacterial cells hidden inside. This contributes to incomplete decontamination since plasma particles exhibit limited ability to penetrate deeper layers of biological material and tend to remain closer to surface.

There is not a unique prototype device for all the applications, but a variety of designs and operating conditions makes it harder to pinpoint all the advantages and disadvantages. For example, APPJ can be the advantageous tool in some fields like medicine and dentistry, where it can be employed in localized decontamination treatment, plasma-induced blood coagulation, wound healing, cancer treatment, and increase of implant biocompatibility. However, in other fields such as food industry, treatment of large and heterogenous surfaces as well as high productivity has to be taken into consideration. The requirement of flowing working gas and small volume of plasma are the limiting factors for design and application of APPJs. DBDs, on the other hand, are more beneficial in treatment of large surfaces and high numbers of samples of different sizes and shapes. The advantage is a minimum or no working gas, high power density of generated plasma, and short exposure times. Most of the plasma devices have been designed for small scale treatments. To successfully transfer plasma technology into industrial settings would require development of such plasma source configurations that enable treatment of a large amount of material in continuous production. The scaling up to industrial (continual) levels could be achieved by attachment of multiple discharge units.

\section{Conclusion}

CAPP technologies in biological sciences have undergone a very dynamic progress in last decade, especially in medicine, food industry, and agriculture. Many benefits of plasma treatment have been frequently accompanied by limitations, such as scaling-up for continuous production, which have to be addressed in future development of novel CAPP technologies. High variability in plasma configurations can be considered both beneficial and limiting. Benefits are related to high number of different plasma sources. However, this can complicate research of plasma-biological target interactions. The plasma
Fig. 2 Advantages and limitations of plasma treatment

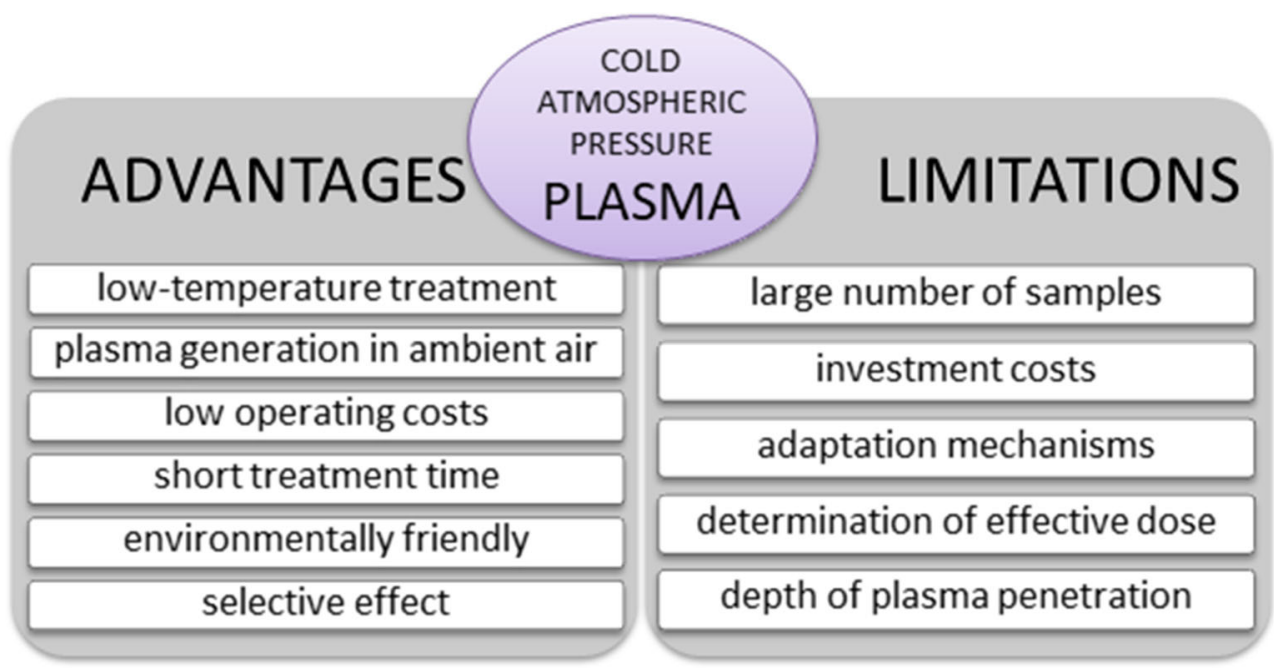


interaction with biological objects can also have adverse effects that have to be considered.

Funding information This work was supported by the Slovak Research and Development Agency under the contract no. APVV-16-0216.

\section{Compliance with ethical standards}

Conflict of interest The authors declare they have no conflict of interest.

Ethical statement This article does not contain any studies with human participants or experimental animals performed by any of the authors.

\section{References}

Arjunan KP, Sharma VK, Ptasinska S (2015) Effects of atmospheric pressure plasmas on isolated and cellular DNA - a review. Int J Mol Sci 16:2971-3016. https://doi.org/10.3390/ijms16022971

Bafoil M, Jemmat A, Martinez Y, Merbahi N, Eichwald O, Dunand C, Yousfi M (2018) Effects of low temperature plasmas and plasma activated waters on Arabidopsis thaliana germination and growth. PLoS One 13:1-16. https://doi.org/10.1371/journal.pone.0195512

Bahrami N, Bayliss D, Chope G, Penson S, Perehinec T, Fisk ID (2016) Cold plasma: a new technology to modify wheat flour functionality. Food Chem 202:247-253. https://doi.org/10.1016/j.foodchem. 2016.01.113

Bekeschus S, Schmidt A, Kramer A, Metelmann HR, Adler F, von Woedtke T, Niessner F, Weltmann KD, Wende K (2018) High throughput image cytometry micronucleus assay to investigate the presence or absence of mutagenic effects of cold physical plasma. Environ Mol Mutagen 59:268-277. https://doi.org/10.1002/em. 22172

Bellan PM (2008) Fundamentals of plasma physics. Cambridge University Press, Cambridge

Bridier A, Sanchez-Vizuete P, Guilbaud M, Piard J, Naïtali M (2015) Biofilm-associated persistence of food-borne pathogens. Food Microbiol 45:167-178. https://doi.org/10.1016/j.fm.2014.04.015

Brun P, Bernabè G, Marchiori C, Scarpa M, Zuin M, Cavazzana R, Zaniol B, Martines E (2018) Antibacterial efficacy and mechanisms of action of low power atmospheric pressure cold plasma: membrane permeability, biofilm penetration and antimicrobial sensitization. $\mathrm{J}$ Appl Microbiol 125:398-408. https://doi.org/10.1111/jam.13780

Campas O, Mahadevan L (2009) Report shape and dynamics of tipgrowing cells. Curr Biol 19:2102-2107. https://doi.org/10.1016/j. cub.2009.10.075

Chatraie M, Torkaman G, Khani M, Salehi H, Shokri B (2018) In vivo study of non-invasive effects of non-thermal plasma in pressure ulcer treatment. Sci Rep 8:5621. https://doi.org/10.1038/s41598$018-24049-\mathrm{z}$

Chirokov A, Gutsol A, Fridman A (2005) Atmospheric pressure plasma of dielectric barrier discharges. 77:487-495. https://doi.org/10.1351/ pac200577020487

Coutinho NM, Silveira MR, Rocha RS, Moraes J, Ferreira MVS, Pimentel TC, Freitas MQ, Silva MC, Raices RSL, Ranadheera CS, Borges FO, Mathias SP, Fernandes FAN, Rodrigues S, Cruz AG (2018) Cold plasma processing of milk and dairy products. Trends Food Sci Technol 74:56-68. https://doi.org/10.1016/j.tifs.2018.02. 008

Cullen PJ, Lalor J, Scally L, Boehm D, Milosavljević V, Bourke P, Keener K (2018) Translation of plasma technology from the lab to the food industry. Plasma Process Polym 15:1-11. https://doi.org/ 10.1002/ppap.201700085
Czapka T, Maliszewska I, Olesiak-Banska J (2018) Influence of atmospheric pressure non-thermal plasma on inactivation of biofilm cells. Plasma Chem Plasma Process 38:1181-1197. https://doi.org/10. 1007/s11090-018-9925-z

Edengeiser E, Lackmann J, Bründermann E, Schneider S, Benedikt J, Bandow JE, Havenith M (2015) Synergistic effects of atmospheric pressure plasma-emitted components on DNA oligomers: a Raman spectroscopic study. J Biophotonics 8:918-924. https://doi.org/10. 1002/jbio.201400123

Foest R, Schmidt M, Becker K (2006) Microplasmas, an emerging field of low-temperature plasma science and technology. Int J Mass Spectrom 248:87-102. https://doi.org/10.1016/j.ijms.2005.11.010

Fridman G, Peddinghaus M, Ayan H, Fridman A, Balasubramanian M, Gutsol A, Brooks A, Friedman G (2006) Blood coagulation and living tissue sterilization by floating-electrode dielectric barrier discharge in air. Plasma Chem Plasma Process 26:425-442. https://doi. org/10.1007/s11090-006-9024-4

Furchtgott L, Wingreen NS, Huang KC (2011) Mechanisms for maintaining cell shape in rod-shaped Gram-negative bacteria. Mol Microbiol 81:340-353. https://doi.org/10.1111/j.1365-2958.2011.07616.x Mechanisms

Graves DB (2014) Low temperature plasma biomedicine: a tutorial review. Phys Plasmas 21:80901. https://doi.org/10.1063/1.4892534

Groot MN, Abee T, van Bokhorst-van de Veen H (2018) Inactivation of conidia from three Penicillium spp. isolated from fruit juices by conventional and alternative mild preservation technologies and disinfection treatments. Food Microbiol 81:0-1. https://doi.org/10. 1016/j.fm.2018.06.004

Guo L, Xu R, Gou L, Liu Z, Zhao Y, Liu D, Zhang L, Chen H, Kong MG (2018a) Mechanism of virus inactivation by cold atmosphericpressure plasma and plasma-activated water. Appl Environ Microbiol 84:726-718. https://doi.org/10.1128/AEM.00726-18

Guo Q, Meng Y, Qu G, Wang T, Yang F, Liang D, Hu S (2018b) Improvement of wheat seed vitality by dielectric barrier discharge plasma treatment. Bioelectromagnetics 39:120-131. https://doi.org/ 10.1002/bem. 22088

Handorf O, Weihe T, Bekeschus S, Graf AC, Schnabel U, Riedel K, Ehlbeck J, Physiology M (2018) Non-thermal plasma jet treatment negatively affects viability and structure of Candida albicans SC5314 biofilms. Appl Environ Microbiol 84:e01163-e01118. https://doi.org/10.1128/AEM.01163-18

Hassan YI, Zhou T (2018) Promising detoxification strategies to mitigate mycotoxins in food and feed. Toxins (Basel) 10:1-5. https://doi.org/ $10.3390 /$ toxins 10030116

He Z, Liu K, Manaloto E, Casey A, Cribaro GP, Byrne HJ, Tian F, Barcia C, Conway GE, Cullen PJ, Curtin JF (2018) Cold atmospheric plasma induces ATP-dependent endocytosis of nanoparticles and synergistic U373MG cancer cell death. Sci Rep 8:1-11. https://doi.org/ 10.1038/s41598-018-23262-0

Huang Y, Ye XP, Doona CJ, Feeherry FE, Radosevich M, Wang S (2018) An investigation of inactivation mechanisms of Bacillus amyloliquefaciens spores in non-thermal plasma of ambient air. J Sci Food Agric 99:368-378. https://doi.org/10.1002/jsfa.9198

Itooka K, Takahashi K, Kimata Y, Izawa S (2018) Cold atmospheric pressure plasma causes protein denaturation and endoplasmic reticulum stress in Saccharomyces cerevisiae. Appl Microbiol Biotechnol 102:2279-2288. https://doi.org/10.1007/s00253-018$8758-2$

Ji SH, Ki SH, Ahn JH, Shin JH, Hong EJ, Kim YJ, Choi EH (2018) Inactivation of Escherichia coli and Staphylococcus aureus on contaminated perilla leaves by dielectric barrier discharge (DBD) plasma treatment. Arch Biochem Biophys 643:32-41. https://doi.org/ 10.1016/j.abb.2018.02.010

Kim JH, Min SC (2018) Moisture vaporization-combined helium dielectric barrier discharge-cold plasma treatment for microbial 
decontamination of onion flakes. Food Control 84:321-329. https:// doi.org/10.1016/j.foodcont.2017.08.018

Kim T, Seo H, Bae H, Kim T, Yang S (2018) Generation of active species and antimicrobial efficacy of an underwater plasma device equipped with a porous bubbler. Plasma Process Polym 15:1-7. https://doi. org/10.1002/ppap.201700229

Kim SY, Bang IH, Min SC (2019) Effects of packaging parameters on the inactivation of Salmonella contaminating mixed vegetables in plastic packages using atmospheric dielectric barrier discharge cold plasma treatment. J Food Eng 242:55-67. https://doi.org/10.1016/j. jfoodeng.2018.08.020

Kogelschatz U, Eliasson B, Egli W, France PIV, Abb E (2003) Dielectricbarrier discharges: their history, discharge physics, and industrial applications. Plasma Chem Plasma Process 23:1-46. https://doi. org/10.1023/A:1022470901385

Lackmann J-W, Schneider S, Edengeiser E, Jarzina F, Brinckmann S, Steinborn E, Havenith M, Benedikt J, Bandow JE (2013) Photons and particles emitted from cold atmospheric-pressure plasma inactivate bacteria and biomolecules independently and synergistically. $\mathrm{J}$ R Soc Interface 10:20130591. https://doi.org/10.1098/rsif.2013. 0591

Laroussi M, Mendis DA, Rosenberg M (2003) Plasma interaction with microbes. New J Phys 5:41

Liao X, Cullen PJ, Liu D, Muhammad AI, Chen S, Ye X, Wang J, Ding T (2018a) Combating Staphylococcus aureus and its methicillin resistance gene (mecA) with cold plasma. Sci Total Environ 645:12871295. https://doi.org/10.1016/j.scitotenv.2018.07.190

Liao X, Li J, Muhammad AI, Suo Y, Chen S, Ye X, Liu D, Ding T (2018b) Application of a dielectric barrier discharge atmospheric cold plasma (Dbd-Acp) for Eshcerichia coli inactivation in apple juice. J Food Sci 83:401-408. https://doi.org/10.1111/1750-3841. 14045

Liao X, Li J, Suo Y, Ahn J, Liu D, Chen S, Hu Y, Ye X, Ding T (2018c) Effect of preliminary stresses on the resistance of Escherichia coli and Staphylococcus aureus toward non-thermal plasma (NTP) challenge. Food Res Int 105:178-183. https://doi.org/10.1016/j.foodres. 2017.11.010

Lin A, Xiang B, Merlino DJ, Baybutt TR, Sahu J, Fridman A, Snook AE, Miller V (2018) Non-thermal plasma induces immunogenic cell death in vivo in murine CT26 colorectal tumors. Oncoimmunology 7:e1484978. https://doi.org/10.1080/2162402X. 2018.1484978

Lis KA, Boulaaba A, Binder S, Li Y, Kehrenberg C, Zimmermann JL, Klein G, Ahlfeld B (2018) Inactivation of Salmonella Typhimurium and Listeria monocytogenes on ham with nonthermal atmospheric pressure plasma. PLoS One 13:1-21

Los A, Ziuzina D, Akkermans S, Boehm D, Cullen PJ, Van IJ, Bourke P (2018) Improving microbiological safety and quality characteristics of wheat and barley by high voltage atmospheric cold plasma closed processing. Food Res Int 106:509-521. https://doi.org/10.1016/j. foodres.2018.01.009

Lu X, Laroussi M, Puech V (2012) On atmospheric-pressure non-equilibrium plasma jets and plasma bullets. Plasma Sources Sci Technol 21:34005. https://doi.org/10.1088/0963-0252/21/3/034005

Ma Y, Yang H, Chen X, Sun B, Du G, Zhou Z, Song J, Fan Y, Shen W (2015) Significantly improving the yield of recombinant proteins in Bacillus subtilis by a novel powerful mutagenesis tool (ARTP): alkaline $\alpha$-amylase as a case study. Protein Expr Purif 114:82-88. https://doi.org/10.1016/j.pep.2015.06.016

Măgureanu M, Sîrbu R, Dobrin D, Gîdea M (2018) Stimulation of the germination and early growth of tomato seeds by non-thermal plasma. Plasma Chem Plasma Process 38:989-1001. https://doi.org/10. 1007/s11090-018-9916-0

Mai-Prochnow A, Clauson M, Hong J, Murphy AB (2016) Gram positive and Gram negative bacteria differ in their sensitivity to cold plasma. Sci Rep 6:1-11. https://doi.org/10.1038/srep38610
Metelmann HR, Seebauer C, Miller V, Fridman A, Bauer G, Graves DB, Pouvesle JM, Rutkowski R, Schuster M, Bekeschus S, Wende K, Masur K, Hasse S, Gerling T, Hori M, Tanaka H, Ha Choi E, Weltmann KD, Metelmann PH, Von Hoff DD, von Woedtke T (2018) Clinical experience with cold plasma in the treatment of locally advanced head and neck cancer. Clin Plasma Med 9:6-13. https://doi.org/10.1016/j.cpme.2017.09.001

Min SC, Roh SH, Niemira BA, Boyd G, Sites JE, Fan X, Sokorai K, Jin TZ (2018) In-package atmospheric cold plasma treatment of bulk grape tomatoes for microbiological safety and preservation. Food Res Int 108:378-386. https://doi.org/10.1016/j.foodres.2018.03.033

Misra NN, Pankaj SK, Segat A, Ishikawa K (2016) Cold plasma interactions with enzymes in foods and model systems. Trends Food Sci Technol 55:39-47. https://doi.org/10.1016/j.tifs.2016.07.001

Mošovská S, Medvecká V, Halászová N, Ďurina P, Valík L', Mikulajová A, Zahoranová A (2018) Cold atmospheric pressure ambient air plasma inhibition of pathogenic bacteria on the surface of black pepper. Food Res Int 106:862-869. https://doi.org/10.1016/j. foodres.2018.01.066

Muhammad AI, Liao X, Cullen PJ, Liu D, Xiang Q, Wang J, Chen S, Ye $X$ (2018) Effects of nonthermal plasma technology on functional food components. 17:1379-1394. doi: https://doi.org/10.1111/ $1541-4337.12379$

Nam SH, Ok SM, Kim GC (2018) Tooth bleaching with low-temperature plasma lowers surface roughness and Streptococcus mutans adhesion. Int Endod J 51:479-488. https://doi.org/10.1111/iej.12860

Nishime TMCC, Borges AC, Koga-ito CY, Machida M, Hein LROO, Kostov KG (2017) Non-thermal atmospheric pressure plasma jet applied to inactivation of different microorganisms. Surf Coat Technol 312:19-24. https://doi.org/10.1016/j.surfcoat.2016.07.076

Pankaj SK (2018) Effects of cold plasma on food quality: a review. Foods 7:4. https://doi.org/10.3390/foods7010004

Pawłat J, Starek A, Sujak A, Terebun P, Kwiatkowski M, Budze M, Andrejko D (2018) Effects of atmospheric pressure plasma jet operating with DBD on Lavatera thuringiaca L . seeds ' germination. PLoS One 13:1-12

Phan KTK, Phan HT, Boonyawan D, Intipunya P, Brennan CS, Regenstein JM, Phimolsiripol Y (2018) Non-thermal plasma for elimination of pesticide residues in mango. Innov Food Sci Emerg Technol 48:164-171. https://doi.org/10.1016/j.ifset.2018.06.009

Pizá MPC, Prevosto L, Zilli C, Cejas E, Kelly H, Balestrasse K (2018) Effects of non - thermal plasmas on seed-borne Diaporthe/ Phomopsis complex and germination parameters of soybean seeds. Innov Food Sci Emerg Technol 49:82-91. https://doi.org/10.1016/j. ifset.2018.07.009

Pykönen M, Silvaani H, Preston J, Fardim P, Toivakka M (2009) Plasma activation induced changes in surface chemistry of pigment coating components. Colloids Surf A Physicochem Eng Asp 352:103-112. https://doi.org/10.1016/j.colsurfa.2009.10.008

Recek N, Zhou RR, Zhou RR, VSJ T'O, Speight RE, Mozetič M, Vesel A, Cvelbar U, Bazaka K, Ostrikov K (2018) Improved fermentation efficiency of $S$. cerevisiae by changing glycolytic metabolic pathways with plasma agitation. Sci Rep 8:1-13. https://doi.org/10. 1038/s41598-018-26227-5

Ritter AC, Santi L, Vannini L, Beys-da-Silva WO, Gozzi G, Yates J, Ragni L, Brandelli A (2018) Comparative proteomic analysis of foodborne Salmonella Enteritidis SE86 subjected to cold plasma treatment. Food Microbiol 76:310-318. https://doi.org/10.1016/j. fm.2018.06.012

Roth JR (2001) Industrial plasma engineering. CRC press, Boca Raton Saadati F, Mahdikia H, Abbaszadeh H-A, Abdollahifar M-A, Khoramgah MS, Shokri B (2018) Comparison of direct and indirect cold atmospheric-pressure plasma methods in the B16F10 melanoma cancer cells treatment. Sci Rep 8:7689. https://doi.org/10.1038/ s41598-018-25990-9 
Sakudo A, Miyagi H, Horikawa T, Yamashiro R, Misawa T (2018) Treatment of Helicobacter pylori with dielectric barrier discharge plasma causes UV induced damage to genomic DNA leading to cell death. Chemosphere 200:366-372. https://doi.org/10.1016/j. chemosphere.2018.02.115

Shaw P, Kumar N, Kwak HS, Park JH, Uhm HS, Bogaerts A, Choi EH, Attri P (2018) Bacterial inactivation by plasma treated water enhanced by reactive nitrogen species. Sci Rep 8:1-10. https://doi. org/10.1038/s41598-018-29549-6

Shi H, Ileleji K, Stroshine RL, Keener K, Jensen JL (2017) Reduction of aflatoxin in corn by high voltage atmospheric cold plasma. Food Bioprocess Technol 10:1042-1052. https://doi.org/10.1007/ s11947-017-1873-8

Siciliano I, Spadaro D, Prelle A, Vallauri D, Cavallero MC, Garibaldi A, Gullino ML (2016) Use of cold atmospheric plasma to detoxify hazelnuts from aflatoxins. Toxins (Basel) 8:125. https://doi.org/10. 3390/toxins 8050125

Šimončicová J, Kaliňáková B, Medvecká V, Lakatoš B, Kryštofová S, Hoppanová L, Palušková V, Hudecová D, Durina P, Zahoranová A (2018) Cold plasma treatment triggers antioxidative defense system and induces changes in hyphal surface and subcellular structures of Aspergillus flavus. Appl Microbiol Biotechnol:1-12

Sivachandiran L, Khacef A (2017) Enhanced seed germination and plant growth by atmospheric pressure cold air plasma: combined effect of seed and water treatment. RSC Adv 7:1822-1832. https://doi.org/ $10.1039 / \mathrm{c} 6 \mathrm{ra} 24762 \mathrm{~h}$

Soler-Arango J (2018) Characterization of an air-based coaxial dielectric barrier discharge plasma source for biofilm eradication. Plasma Chem Plasma Process 38:535-556. https://doi.org/10.1007/ s11090-018-9877-3

Song W, Wang E, Gao Y, Wu Q, Rao S, Wang H, Bao L (2018) Low temperature plasma induced apoptosis in CNE-2Z cells through endoplasmic reticulum stress and mitochondrial dysfunction pathways. Plasma Process Polym 15:1-9. https://doi.org/10.1002/ppap. 201600249

Štěpánová V, Slavíček P, Kelar J, Prášil J, Smékal M, Stupavská M, Jurmanová J, Černák M (2018) Atmospheric pressure plasma treatment of agricultural seeds of cucumber (Cucumis sativus L.) and pepper (Capsicum annuum L.) with effect on reduction of diseases and germination improvement. Plasma Process Polym 15:1-9. https://doi.org/10.1002/ppap.201700076

Stoffels E, Sakiyama Y, Graves DB (2008) Cold atmospheric plasma: charged species and their interactions with cells and tissues. IEEE Trans Plasma Sci 36:1441-1457. https://doi.org/10.1109/TPS.2008. 2001084

Su X, Tian Y, Zhou H, Li Y, Zhang Z, Jiang B, Yang B, Zhang J, Fang J (2018) Inactivation efficacy of nonthermal plasmaactivated solutions against Newcastle disease virus. Appl Environ Microbiol 84. https://doi.org/10.1128/AEM.02836-17

Sun Y, Zhang Z, Wang S (2018) Study on the bactericidal mechanism of atmospheric-pressure low-temperature plasma against Escherichia coli and its application in fresh-cut cucumbers. Molecules 23:975. https://doi.org/10.3390/molecules23040975

Suwal S, Coronel-Aguilera CP, Auer J, Applegate B, Garner AL, Huang JY (2018) Mechanism characterization of bacterial inactivation of atmospheric air plasma gas and activated water using bioluminescence technology. Innov Food Sci Emerg Technol 53:18-25. https:// doi.org/10.1016/j.ifset.2018.01.007

Takai E, Kitano K, Kuwabara J, Shiraki K (2012) Protein inactivation by low-temperature atmospheric pressure plasma in aqueous solution. Plasma Process Polym 9:77-82. https://doi.org/10.1002/ppap. 201100063

ten Bosch L, Pfohl K, Avramidis G, Wieneke S, Viöl W, Karlovsky P, ten Bosch L, Pfohl K, Avramidis G, Wieneke S, Viöl W, Karlovsky P (2017) Plasma-based degradation of mycotoxins produced by
Fusarium, Aspergillus and Alternaria species. Toxins (Basel) 9:112. https://doi.org/10.3390/toxins9030097

Timmons C, Pai K, Jacob J, Zhang G, Maria L, Ma LM (2018) Inactivation of Salmonella enterica, Shiga toxin-producing Escherichia coli, and Listeria monocytogenes by a novel surface discharge cold plasma design. Food Control 84:455-462. https:// doi.org/10.1016/j.foodcont.2017.09.007

Van Der Paal J, Neyts EC, Verlackt CCW, Bogaerts A (2016) Effect of lipid peroxidation on membrane permeability of cancer and normal cells subjected to oxidative stress. Chem Sci 7:489-498. https://doi. org $/ 10.1039 / \mathrm{c} 5 \mathrm{sc} 02311 \mathrm{~d}$

Wang HY, Zhang J, Zhang YJ, Zhang B, Liu CX, He HR, Wang XJ, Xiang WS (2014) Combined application of plasma mutagenesis and gene engineering leads to 5-oxomilbemycins A3/A4 as main components from Streptomyces bingchenggensis. Appl Microbiol Biotechnol 98:9703-9712. https://doi.org/10.1007/s00253-0145970-6

Weltmann K-D, von Woedtke T (2011) Basic requirements for plasma sources in medicine. Eur Phys J Appl Phys 55:13807. https://doi. org/10.1051/epjap/2011100452

Winter S, Meyer-Lindenberg A, Wolf G, Reese S, Nolff MC (2018) In vitro evaluation of the decontamination effect of cold argon plasma on selected bacteria frequently encountered in small animal bite injuries Short title: In vitro CAP evaluation. BioRxiv 353821

Wu F (2015) Global impacts of aflatoxin in maize: trade and human health. World Mycotoxin J 8:137-142. https://doi.org/10.3920/ WMJ2014.1737

Xiang Q, Liu X, Li J, Liu S, Zhang H, Bai Y (2018) Effects of dielectric barrier discharge plasma on the inactivation of Zygosaccharomyces rouxii and quality of apple juice. Food Chem 254:201-207. https:// doi.org/10.1016/j.foodchem.2018.02.008

Xu D, Cui Q, Xu Y, Wang B, Tian M, Li Q, Liu Z, Liu D, Chen H, Kong M (2018a) Systemic study on the safety of immuno-deficient nude mice treated by atmospheric plasma-activated water. Plasma Sci Technol 20:44003. https://doi.org/10.1088/2058-6272/aa9842

Xu D, Xu Y, Cui Q, Liu D, Liu Z, Wang X, Yang Y, Feng M, Liang R, Chen H, Ye K, Kong MG (2018b) Cold atmospheric plasma as a potential tool for multiple myeloma treatment. Oncotarget 9:1800218017. https://doi.org/10.18632/oncotarget.24649

Xu D, Xu Y, Ning N, Cui Q, Liu Z, Wang X, Liu D, Chen H, Kong MG (2018c) Alteration of metabolite profiling by cold atmospheric plasma treatment in human myeloma cells. Cancer Cell Int 18:1-11. https://doi.org/10.1186/s12935-018-0541-Z

$\mathrm{Xu}$ Z, Cheng C, Shen J, Lan Y, Hu S, Han W, Chu PK (2018d) In vitro antimicrobial effects and mechanisms of direct current air-liquid discharge plasma on planktonic Staphylococcus aureus and Escherichia coli in liquids. Bioelectrochemistry 121:125-134. https://doi.org/10.1016/j.bioelechem.2018.01.012

Yang Y, Guo J, Zhou X, Liu Z, Wang C, Wang K, Zhang J, Wang Z (2018) A novel cold atmospheric pressure air plasma jet for periimplantitis treatment: An in vitro study. Dent Mater J 37:157-166. https://doi.org/10.4012/dmj.2017-030

Zahoranová A, Hoppanová L, Šimončicová J, Tučeková Z, Medvecká V, Hudecová D, Kaliňáková B, Kováčik D, Černák M (2018) Effect of cold atmospheric pressure plasma on maize seeds: enhancement of seedlings growth and surface microorganisms inactivation. Plasma Chem Plasma Process 38:969-988. https://doi.org/10.1007/s11090018-9913-3

Zhang XFX, Zhang C, Zhou QQ, Zhang XFX, Wang LY, Chang HB, Li HP, Oda Y, Xing XH (2015) Quantitative evaluation of DNA damage and mutation rate by atmospheric and room-temperature plasma (ARTP) and conventional mutagenesis. Appl Microbiol Biotechnol 99:5639-5646. https://doi.org/10.1007/s00253-015-6678-y

Zhang JJ, Jo JO, Huynh DL, Ghosh M, Kim N, Lee SB, Lee HK, Mok YS, Kwon T, Jeong DK (2017) Lethality of inappropriate plasma 
exposure on chicken embryonic development. Oncotarget 8:8564285654. https://doi.org/10.18632/oncotarget.21105

Zhang B, Li R, Yan J (2018a) Study on activation and improvement of crop seeds by the application of plasma treating seeds equipment. Arch Biochem Biophys 655:37-42. https://doi.org/10.1016/j.abb. 2018.08.004

Zhang JJ, Do HL, Chandimali N, Lee SB, Mok YS, Kim N, Kim SB, Kwon T, Jeong DK (2018b) Non-thermal plasma treatment improves chicken sperm motility via the regulation of demethylation levels. Sci Rep 8:7576. https://doi.org/10.1038/s41598-018-26049-5

Zhang JJ, Huynh DL, Chandimali N, Kang TY, Kim N, Mok YS, Kwon T, Jeong DK (2018c) Growth and male reproduction improvement of non-thermal dielectric barrier discharge plasma treatment on chickens. J Phys D Appl Phys 51:205201

Zhang JJ, Wang XZ, Kwon T, Huynh DL, Chandimali N, Kim N, Kang TY, Ghosh M, Gera M, Lee SB, Lee SJ, Lee WS, Kim SB, Mok YS, Jeong DK (2018d) Innovative approach of non-thermal plasma application for improving the growth rate in chickens. Int J Mol Sci 19: 1-19. https://doi.org/10.3390/ijms19082301
Zhang Y, Xiong Y, Xie P, Ao X, Zheng Z, Dong X, Li H, Yu Q, Zhu Z, Chen M, Chen W (2018e) Non-thermal plasma reduces periodontitis-induced alveolar bone loss in rats. Biochem Biophys Res Commun 503:2040-2046. https://doi.org/10.1016/j.bbrc.2018. 07.154

Zhao B, Li Y, Li C, Yang H, Wang W (2018) Enhancement of Schizochytrium DHA synthesis by plasma mutagenesis aided with malonic acid and zeocin screening. Appl Microbiol Biotechnol 102: 2351-2361. https://doi.org/10.1007/s00253-018-8756-4

Ziuzina D, Boehm D, Patil S, Cullen PJ, Bourke P (2015) Cold plasma inactivation of bacterial biofilms and reduction of quorum sensing regulated virulence factors. PLoS One 10:1-21. https://doi.org/10. 1371/journal.pone.0138209

Publisher's note Springer Nature remains neutral with regard to jurisdictional claims in published maps and institutional affiliations. 